\title{
Oral bacteria detection among children with cancer in a tertiary teaching hospital in Kuala Lumpur, Malaysia
}

\author{
Sidi Omar, S.F.N. ${ }^{1}$, Ngui, R. ${ }^{1}{ }^{*}$, Ab Rahman, S.Z. ${ }^{2}$, Foo, J.C. ${ }^{2}$, Wang, Q.Y. ${ }^{2}$, Hassan, N.A. ${ }^{1}$, Lim, Y.A.L. ${ }^{1}$, \\ Musa, S. $^{3^{*}}$
}

${ }^{1}$ Department of Parasitology, Faculty of Medicine, Universiti Malaya, 50603 Kuala Lumpur, Malaysia

${ }^{2}$ Department of Paediatrics, Faculty of Medicine, Universiti Malaya, 50603 Kuala Lumpur, Malaysia

${ }^{3}$ Department of Paediatric Dentistry \& Orthodontics, Faculty of Dentistry, Universiti Malaya, 50603, Kuala Lumpur, Malaysia

*Corresponding authors: sabrim@um.edu.my / romano@um.edu.my

\section{ARTICLE HISTORY}

Received: 27 April 2021

Revised: 28 June 2021

Accepted: 28 June 2021

Published: 31 July 2021

\begin{abstract}
This study sought to determine the prevalence of pathogenic and non-pathogenic bacteria in the oral cavities of children with cancer. There were 68 paediatric patients with cancer who were included in this study. Oral swab samples from the dorsum of tongues and mouth floors of these patients were subjected to culture, staining, and molecular methods to detect the bacteria. The overall prevalence of gram-positive and gram-negative bacteria was $79.4 \%(54 / 68 ; 95 \% \mathrm{Cl}=68.4-87.3)$ and $25 \%(17 / 68 ; 95 \% \mathrm{Cl}=16.2-36.4)$, respectively. Streptococcus salivarius and Streptococcus parasanguinis were the predominant pathogenic grampositive bacteria, while Neisseria subflava and Neisseria perflava were the most common pathogenic gram-negative bacteria. The results revealed that the number of bacteria isolates recovered in patients receiving cancer treatment was higher $(55.9 \%)$ than those who had not received treatment (16.2\%). Therefore, more isolated pathogenic bacteria were observed post-therapy (54.4\%). Pathogenic organisms can have significant implications on patient health. Awareness of the types of bacteria inhabiting the oral cavity is essential to predict and prevent dental problems, and their associated systemic complications. Findings on the diversity of oral microflora can also provide a better understanding of the aetiology of oral diseases in paediatric patients receiving cancer treatment.
\end{abstract}

Keywords: Oral bacteria; paediatric; cancer; gram-staining; molecular method.

\section{INTRODUCTION}

The oral cavity is the second most complex microbiota in the body after the gut (Verma et al., 2018; Zhang et al., 2018; Kitamoto et al., 2020). Nearly 800 microbial species have been identified, mainly bacteria, fungi, viruses, and parasites (Sampaio-Maia et al., 2016; Verma et al., 2018; Zhang et al., 2018). In healthy individuals, these microbial communities serve as commensals that can influence the host immune system to maintain homeostasis (Mira et al., 2017). However, if the balance is disrupted, such as in the immunocompromised host, the oral cavity will be colonized by potentially pathogenic species, leading to various diseases (Idris et al., 2017). Some of these pathogens may be responsible for life-threatening infections.

Despite significant advances in treatment and supportive care, cancer predisposes patients to serious infections (Villafuerte et al., 2018; Daugëlaitë et al., 2019; Nivoix et al., 2020). Cancer itself or chemotherapy can disrupt the intricate balance between commensal bacteria and the host defence mechanism, resulting in the spread of potentially life- threatening infections leading to ruptures in the oral mucosal tissues (Villafuerte et al., 2018; Bunetel et al., 2019), resulting in severe oral mucositis (Hong et al., 2019), oral candidiasis (Bertolini \& Dongari-Bagtzoglou, 2019), gingivitis (Curtis et al., 2020), viral mucosal eruptions, and cellulitis (Crescente et al., 2018; Miranda-Silva et al., 2020). The oral microflora may subsequently be replaced by potentially pathogenic organisms like Staphylococcus aureus, Pseudomonas aeruginosa, and Candida species (Kong et al., 2015; Bunetel et al., 2019).

Within the oral cavity, bacterial populations result from the dynamic relationship between pathogens and commensals (Bowen et al., 2018). Oral bacteria have been implicated in causing bacterial endocarditis (Abranches et al., 2018), aspiration pneumonia (Maraki \& Papadakis, 2015), osteomyelitis in children (Castellazzi et al., 2016), preterm low birth weight (Ye et al., 2020), coronary heart disease (Liu et al., 2020; Priyamvara et al., 2020), and cerebral infarction (Patrakka et al., 2019). The incidence of bacteremia following dental procedures has been well documented (Cahill et al., 2017; Fernández et al., 2018). Oral mucositis has been 
identified in several studies as an independent risk factor for bacteraemia and systemic infections, involving anaerobic bacteria and other species generally not found in the oral cavity (Lecomte et al., 2017).

Knowledge of the type of bacteria that inhabit the oral cavity is essential in predicting and preventing dental diseases and the associated systemic complications caused by them (Chimenos-Küstner et al., 2017; Graves et al., 2019). It is known that opportunistic pathogens are widespread among patients with cancer. However, knowledge of the micro-organisms and their associations with clinical manifestation is scarce. Therefore, this study was carried out to determine the prevalence of oral bacteria present in the oral cavities of children with cancer. The molecular approach to determine specific species levels will aid in more accurate diagnosis and treatment. In addition, such information will provide invaluable insights into the epidemiology of these infections, thus facilitating the understanding of the clinical diseases, diagnoses, and management.

\section{MATERIALS AND METHODS}

\section{Study Design and Participants}

This study was approved by the Medical Ethics Committee of the University of Malaya Medical Centre (MREC ID NO: 20195287454). Convenience sampling was conducted in the Paediatric Oncology Unit, University of Malaya Medical Centre from August 2019 to September 2020. Participants were between the ages of 1 year to 18 years and diagnosed with cancer. They were recruited from the oncology ward and from the paediatric oncology daycare unit. They had not taken antibiotics in the previous month. Written consent was obtained from parents or relatives after verbal information was provided. The participants were divided into two groups: (1) patients who had not received cancer therapy (chemotherapy or radiotherapy), and (2) patients who were on cancer therapy. Demographic information such as age, gender, diagnosis, and date of cancer therapy was retrieved from their hospital records. All information obtained in the study was kept confidential and accessible only to researchers involved in this study.

\section{Sample Collection and Staining}

Samples were collected by gently rubbing a sterile cotton swab on the dorsum of the tongues and the floor of the mouths using Stuart with charcoal media Transport Swab (Labchem, Malaysia). The swabs were sent to the Emerging Pathogen Laboratory 2, Department of Parasitology, Faculty of Medicine, University of Malaya, within 2 hours of collection. The swabbed samples were plated on Columbia blood agar with $5 \%$ sheep blood (Isolab, Malaysia) and incubated aerobically at $37^{\circ} \mathrm{C}$ for $3-5$ days. Distinct colonies (2-3 colonies of apparently similar morphology) were selected from mixed growth and streaked separately on a new blood agar plate until a pure culture was obtained. Single colonies obtained from the pure culture were characterized grossly by colour and shape, and by microscopy.

Gram staining was performed on a single colony from the pure culture using a gram-stain kit according to the manufacturer's instructions (Condalab, Madrid, Spain). A single colony smeared on sterile distilled water was fixed on a glass slide by flaming briefly. Next, the smears were stained for 1 minute with crystal violet and iodine solutions, briefly rinsed with a decolourizer for 10 seconds, and stained with safranin solution. Each step was accompanied by washing with sterile water. The slides were air-dried and observed under a light microscope at high magnification (x100) with immersion oil. The bacteria colonies were graded as gram-positive if they were purplish-blue in colour or gramnegative when a red colour was observed.

\section{DNA Extraction}

Based on the manufacturer's instructions, the genomic DNA from the pure cultures were extracted using GF-1 spin Bacterial DNA extraction mini kit (Vivantis Technologies, Malaysia). Approximately 10 to 15 colonies selected from the pure cultures were re-suspended in buffer R1 and incubated at $37^{\circ} \mathrm{C}$ for $20 \mathrm{~min}$ with a cell lysis agent. The pellet obtained was subjected to protein denaturation and homogenization for complete cell lysis. The DNA was eluted with an elution buffer to a final volume of $50 \mu \mathrm{L}$. The extracted DNA was stored at $-20^{\circ} \mathrm{C}$ until required for amplification by Polymerase Chain Reaction (PCR).

\section{Amplification of $16 \mathrm{~S}$ rDNA by PCR}

16S rDNA genes were amplified using a set of universal primers: 27f: 5'-AGA GTT TGA TCA TGG CTC AG and 149r: 5'-TAC GGC TAC CTT GTT ACG ACT T (Philip et al., 2009). The PCR was performed in a $20 \mu \mathrm{L}$ reaction mixture containing $10 \mu \mathrm{L}$ of the master mix (Genet Bio, South Korea), $2 \mu \mathrm{L}$ each of forward and reverse primers, $4 \mu \mathrm{L}$ of distilled water, and $2 \mu \mathrm{L}$ of the DNA template. Both negative (reagent mixture without template DNA) and positive controls were included in each PCR set. The amplification steps were initially denatured at $94^{\circ} \mathrm{C}$ for $5 \mathrm{~min}$, followed by 32 cycles of denaturation at $94^{\circ} \mathrm{C}$ for $30 \mathrm{sec}$, annealing at $50^{\circ} \mathrm{C}$ for $40 \mathrm{sec}$, extension at $72^{\circ} \mathrm{C}$ for $1 \mathrm{~min}$, and a final extension at $72^{\circ} \mathrm{C}$ for $5 \mathrm{~min}$. The amplified DNA was analysed by gel electrophoresis in $1.5 \%(\mathrm{w} / \mathrm{v})$ agarose gel stained with SYBR ${ }^{\circ}$ Safe DNA (Invitrogen, Auckland, New Zealand) to visualize the amplified PCR product under UV illumination.

The PCR product was subjected to DNA commercial sequencing. Sequence chromatograms were viewed using Sequence Scanner version 1.0 program (Applied Biosystems, Waltham, MA, USA). Both forward and reverse nucleotide sequences were manually aligned using the BioEdit Sequence Alignment Editor version 7.0.9 program. Sequences were blasted to the National Centre for Biotechnology Information (NCBI) databases using Basic Local Alignment Search Tool (BLAST). The bacterial species were identified based on $98 \%$ similarity to the $16 \mathrm{~S}$ RNA sequence database. Cross-reference was also made to the Human Oral Microbiome Database (HOMD).

\section{Statistical Analyses}

Statistical analyses were performed using SPSS software (Statistical Package for the Social Sciences, version 25.0, SPSS Inc, Chicago, III, USA). Categorical variables were presented as frequency (percentage) and 95\% confidence interval (95\% $\mathrm{Cl})$. Where appropriate, a Chi-square test or Fisher's exact test was performed to determine any differences among the groups. A $p$-value of less than 0.05 was considered significant.

\section{RESULTS}

There were 68 individuals recruited for this study. There were $41(60.3 \%)$ male and 27 (39.7\%) females, respectively. Forty seven (69.1\%) were Malay, 19 (28\%) Chinese, and 2 (2.9\%) Indian (Table 1). Median age was 7 years (range: 1 year to 18 years). Of the 64 patients with complete datasets, most were diagnosed with acute leukaemia (66\%). Eight (11.8\%) had bone cancer, $7(10.3 \%)$ had central nervous system malignancies, 3 had germ cell tumours and lymphoma (4.4\%), 
$2(2.9 \%)$ had Langerhans cell histiocytosis, and 1 (1.5\%) had nasopharyngeal carcinoma. Of the 56 patients with complete datasets, the majority were actively undergoing cancer therapy ( $n=43,63.2 \%)$, while 13 (19.1\%) were newly-diagnosed patients who had not received cancer treatment.

The gram staining showed that the overall prevalence of gram-positive and gram-negative bacteria was $79.4 \%$ $(54 / 68 ; 95 \% \mathrm{Cl}=68.4-87.3)$ and $25 \%(17 / 68 ; 95 \% \mathrm{Cl}=16.2-36.4)$, respectively. Table 2 shows the prevalence of gram-positive and gram-negative aerobic bacteria from the oral cavities of paediatric patients based on pathogenicity. Gram-positive bacteria was most common $(57.4 \% ; 95 \% \mathrm{Cl}=45.5-68.4)$ followed by both gram-positive and gram-negative aerobic bacteria $(22.1 \% ; 95 \% \mathrm{Cl}=13.9-33.3)$ and gram-negative bacteria alone $(2.9 \% ; 95 \% \mathrm{Cl}=0.8-10.1)$. A total of $51(75 \%$; $95 \% \mathrm{Cl}=63.6-83.8)$ isolates were reported as pathogenic bacteria. Of these, $55.9 \%(95 \% \mathrm{Cl}=44.1-67.1)$ were identified as gram-positive while $2.9 \%(95 \% \mathrm{Cl}=0.8-10.1)$ were gramnegative. Both gram-positive and negative bacteria were observed in $20.6 \%(95 \% \mathrm{Cl}=12.7-31.6)$. Meanwhile, $7.4 \%$ $(95 \% \mathrm{Cl}=3.2-16.1)$ isolates were recorded as non-pathogenic species. Of these, $1.5 \%(95 \% \mathrm{Cl}=0.3-7.9)$ were identified as gram-positive while both gram-positive and negative bacteria

Table 1. Demographic characteristics of participants $(N=68)$

\begin{tabular}{lc}
\hline Characteristics & $\mathrm{n}(\%)$ \\
\hline Gender & \\
Male & $41(60.3)$ \\
Female & $27(39.7)$ \\
Age in years (median range) & $7(1-18)$ \\
Age Group (Years) & \\
$1-6$ & $30(44.1)$ \\
$7-12$ & $24(35.3)$ \\
13-18 & $14(20.6)$ \\
Race & \\
Malay & $47(69.1)$ \\
Chinese & $19(28)$ \\
Indian & $2(2.9)$ \\
Type of Cancera & \\
Leukaemia & $40(66)$ \\
Bone & $8(11.8)$ \\
Central Nervous System & $7(10.3)$ \\
Germ Cell & $3(4.4)$ \\
Lymphoma & $3(4.4)$ \\
Langerhans Cell Histiocytosis & $2(2.9)$ \\
Nasopharynx & $1(1.5)$ \\
Cancer Treatment & \\
Before treatment & $13(19.1)$ \\
After treatment & $43(63.2)$ \\
\hline
\end{tabular}

$\mathrm{N}=$ Total number of participants; $\mathrm{n}=$ Total number of participants per variable. A total of 52 and 45 patient information according to cancer type ( ${ }^{\mathrm{a}}$ ) and therapy $\left({ }^{b}\right)$, respectively was used for the analysis. were observed in $1.5 \%(95 \% \mathrm{Cl}=0.3-7.9)$ of these patients.

A total of 102 bacterial isolates were recovered from the 58 paediatric patients in this study (Table 3 ). Of these, 58 $(56.9 \% ; 95 \% \mathrm{Cl}=47.1-66.1)$ were gram-positive and 2 (2\%; $95 \% \mathrm{Cl}=0.5-6.9)$ were gram-negative bacteria. Additionally,

Table 3. Prevalence of aerobic bacterial species in the oral cavity of paediatric patients

\begin{tabular}{|c|c|c|}
\hline Bacterial species & $n(\%)$ & $95 \% \mathrm{Cl}$ \\
\hline \multicolumn{3}{|l|}{ Gram-positive } \\
\hline \multicolumn{3}{|l|}{ Pathogenic } \\
\hline Streptococcus salivarius & $20(19.6)$ & $13.1-28.4$ \\
\hline Streptococcus parasanguinis & $11(10.8)$ & $6.1-18.3$ \\
\hline Rothia mucilaginosa & $4(3.9)$ & $1.5-9.7$ \\
\hline Staphylococcus aureus & $4(3.9)$ & $1.5-9.7$ \\
\hline Streptococcus australis & $4(3.9)$ & $1.5-9.7$ \\
\hline Streptococcus mitis & $4(3.9)$ & $1.5-9.7$ \\
\hline Actinomyces oris & $2(2)$ & $0.5-6.9$ \\
\hline Streptococcus gordonii & $2(2)$ & $0.5-6.9$ \\
\hline Corynebacterium argentoratense & $1(1)$ & $0.2-5.3$ \\
\hline Corynebacterium durum & $1(1)$ & $0.2-5.3$ \\
\hline Streptococcus anginosus & $1(1)$ & $0.2-5.3$ \\
\hline Streptococcus cristatus & $1(1)$ & $0.2-5.3$ \\
\hline Streptococcus infantis & $1(1)$ & $0.2-5.3$ \\
\hline Streptococcus oralis & $1(1)$ & $0.2-5.3$ \\
\hline \multicolumn{3}{|l|}{ Non-pathogenic } \\
\hline Streptococcus sanguinis & $1(1)$ & $0.2-5.3$ \\
\hline Overall & $58(56.9)$ & $47.1-66.1$ \\
\hline \multicolumn{3}{|l|}{ Gram-negative } \\
\hline \multicolumn{3}{|l|}{ Pathogenic } \\
\hline Acinetobacter baumannii & $1(1)$ & $0.2-5.3$ \\
\hline Neisseria subflava & $1(1)$ & $0.2-5.3$ \\
\hline Overall & $2(2)$ & $0.5-6.9$ \\
\hline \multicolumn{3}{|l|}{ Both } \\
\hline \multicolumn{3}{|l|}{ Pathogenic } \\
\hline Streptococcus salivarius & $11(10.8)$ & $6.1-18.3$ \\
\hline Streptococcus parasanguinis & $5(4.9)$ & $2.1-11$ \\
\hline Neisseria subflava & $4(3.9)$ & $1.5-9.7$ \\
\hline Neisseria perflava & $4(3.9)$ & $1.5-9.7$ \\
\hline Neisseria mucosa & $3(2.9)$ & $1.0-8.3$ \\
\hline Streptococcus infantis & $3(2.9)$ & $1.0-8.3$ \\
\hline Neisseria flava & $2(2)$ & $0.5-6.9$ \\
\hline Acinetobacter baumannii & $2(2)$ & $0.5-6.9$ \\
\hline Streptococcus mitis & $2(2)$ & $0.5-6.9$ \\
\hline Actinomyces oris & $1(1)$ & $0.2-5.3$ \\
\hline Actinomyces naes/undii & $1(1)$ & $0.2-5.3$ \\
\hline Klebsiella pneumoniae & $1(1)$ & $0.2-5.3$ \\
\hline Rothia aeria & $1(1)$ & $0.2-5.3$ \\
\hline Rothia mucilaginosa & $1(1)$ & $0.2-5.3$ \\
\hline \multicolumn{3}{|l|}{ Non-pathogenic } \\
\hline Streptococcus sanguinis & $1(1)$ & $0.2-5.3$ \\
\hline Overall & $42(41.2)$ & $32.1-50.9$ \\
\hline
\end{tabular}

$\mathrm{n}=$ Total number of patients per bacterial species.

Table 2. Prevalence of gram-positive and gram-negative bacteria isolated from the oral cavity of paediatric patients

\begin{tabular}{|c|c|c|c|c|c|c|}
\hline & \multicolumn{2}{|c|}{ Pathogenic } & \multicolumn{2}{|c|}{ Non-pathogenic } & \multicolumn{2}{|c|}{ Total } \\
\hline & n (\%) & $95 \% \mathrm{Cl}$ & n (\%) & $95 \% \mathrm{Cl}$ & N (\%) & $95 \% \mathrm{Cl}$ \\
\hline Gram-positive & 38 (55.9) & $44.1-67.1$ & $1(1.5)$ & $0.3-7.9$ & $39(57.4)$ & $45.5-68.4$ \\
\hline Gram-negative & $2(2.9)$ & $0.8-10.1$ & 0 & - & $2(2.9)$ & $0.8-10.1$ \\
\hline Both & $14(20.6)$ & $12.7-31.6$ & $1(1.5)$ & $0.3-7.9$ & $15(22.1)$ & $13.9-33.3$ \\
\hline Total & $51(75)$ & $63.6-83.8$ & $5(7.4)$ & $3.2-16.1$ & $56(82.4)$ & $71.6-89.6$ \\
\hline
\end{tabular}

$\mathrm{N}=$ Total number of participants; $\mathrm{n}=$ Total number of participants per variable. 
Table 4. Distribution of gram-positive and gram-negative bacteria based on the demographic characteristic $(\mathrm{N}=58)$

\begin{tabular}{|c|c|c|c|c|c|c|c|}
\hline \multirow{2}{*}{ Characteristics } & \multirow{2}{*}{ Overall (\%) } & \multicolumn{2}{|c|}{ Gram-positive } & \multicolumn{2}{|c|}{ Gram-negative } & \multicolumn{2}{|c|}{ Both } \\
\hline & & $\mathrm{n}(\%)$ & P-value & n (\%) & P-value & $\mathrm{n}(\%)$ & P-value \\
\hline \multicolumn{8}{|l|}{ Gender } \\
\hline Male & 33 (48.5\%) & $21(30.9)$ & 0.24 & $2(2.9)$ & 0.507 & $10(14.7)$ & 0.48 \\
\hline Female & $23(33.8 \%)$ & $18(26.5)$ & & - & & $5(7.4)$ & \\
\hline \multicolumn{8}{|l|}{ Age Group (Years) } \\
\hline Less than 7 & 31 (45.6) & $17(25.0)$ & $0.007^{*}$ & $2(2.9)$ & 0.497 & 12 (17.6) & $0.03^{*}$ \\
\hline More than 7 & $25(36.8)$ & $22(32.4)$ & & - & & $3(4.4)$ & \\
\hline \multicolumn{8}{|l|}{ Race } \\
\hline Malay & 41 (60.3\%) & $30(44.1)$ & 0.23 & $2(3.4)$ & 0.660 & $8(11.8)$ & 0.11 \\
\hline Chinese & $15(22.1 \%)$ & $8(11.8)$ & & - & & $7(10.3)$ & \\
\hline Indian & $2(2.9 \%)$ & $1(1.5)$ & & - & & - & \\
\hline \multicolumn{8}{|l|}{ Type of Cancer } \\
\hline Leukaemia & $34(50.0)$ & $22(32.4)$ & 0.15 & $2(2.9)$ & 0.981 & $10(14.7)$ & 0.13 \\
\hline Bone & $7(10.3)$ & $6(8.8)$ & & - & & $1(1.5)$ & \\
\hline CNS & $4(5.9)$ & $3(4.4)$ & & - & & $1(1.5)$ & \\
\hline Germ Cell & $3(4.4)$ & $3(4.4)$ & & - & & - & \\
\hline Lymphoma & $1(1.5)$ & 0 & & - & & $1(1.5)$ & \\
\hline Langerhans Cell Histiocytosis & $2(2.9)$ & 0 & & - & & $2(2.9)$ & \\
\hline Nasopharynx & $1(1.5)$ & $1(1.5)$ & & - & & - & \\
\hline \multicolumn{8}{|l|}{ Cancer Treatment } \\
\hline Before therapy & $11(16.2)$ & $6(8.8)$ & $0.022 *$ & $1(1.5)$ & 0.402 & $4(5.9)$ & 0.71 \\
\hline After therapy & $38(55.9)$ & $27(39.7)$ & & $1(1.5)$ & & $10(14.7)$ & \\
\hline
\end{tabular}

$\mathrm{N}=$ Total number of bacterial isolates; $\mathrm{n}=$ Total number of bacterial isolates per variable.

* Significant difference, $\mathrm{p}<0.05$, based on Chi Square Test.

42 (41.2\%; $95 \% \mathrm{Cl}=32.1-50.9)$ had other bacteria species isolated. As seen in Table 3, the Streptococci and Neisseria species were the most frequently isolated gram-positive and gram-negative bacteria, respectively. Of the pathogenic gram-positive bacteria, Staphylococcus aureus $(2 \% ; 95 \% \mathrm{Cl}=0.5$ - 6.9) was reported among these patients while Klebsiella pneumoniae $(1 \% ; 95 \% \mathrm{Cl}=0.2-5.3)$ was detected in the pathogenic gram-negative bacteria. Table 3 also provides details on other bacterial species reported in this study.

Based on age groups, there was a significant difference between patients above 7 years (32.4\%) infected with grampositive bacteria compared to those who were younger $(25 \%)(p=0.007)$ (Table 4). Additionally, $12(17.6 \%)$ of the patients below the age of 7 years had both gram-positive and gram-negative bacteria compared to $3(4.4 \%)$ in the older age group $(p=0.03)$. In general, the number of bacteria isolates recovered were significantly higher in patients who had received cancer treatment $(55.9 \%)$ compared to those who had not $(16.2 \%)(p<0.05)$. Similarly, the number of patients with gram-positive bacteria were significantly higher among those receiving treatment $(39.7 \%)$ compared to those before treatment $(8.8 \%)(p=0.022)$. In addition, more bacteria with both types of gram stains were observed among patients receiving cancer treatment (14.7\%). Streptococcus salivarius and Streptococcus parasanguinis had the highest prevalence $(22.5 \%$ vs $3.9 \%$ and $9.8 \%$ vs $3.9 \%$, respectively) in patients who had received cancer therapy than those who had not received treatment. Furthermore, other bacterial species such as Corynebacterium durum, Rothia mucilaginosa, S. aureus, Acinetobacter baumannii, Klebsiella pneumoniae, and viridans streptococci like Streptococcus anginosus, Streptococcus australis, Streptococcus cristatus, Streptococcus gordonii, Streptococcus infantis, and Streptococcus oralis were more common in those who had cancer therapy (data not shown).

\section{DISCUSSION}

This study describes the prevalence of bacteria in the oral cavities of children with cancer. Gram-positive bacteria were most common, with viridans streptococci being the most frequently isolated organism. Similar findings were reported by Sixou et al. (1998). However, another study found that gram-negative bacteria were commonly isolated (52.6\%), followed by gram-positive bacteria (45\%) (Tang et al., 2020). Furthermore, among paediatric patients with acute leukaemia gram-negative bacteria, gram-positive bacteria, and fungi constituted $56.3 \%, 42.3 \%$, and $2.4 \%$ of oral cavity isolates, respectively (Kuo et al., 2017). Major gram-negative bacteria observed included $K$. pneumonia, Pseudomonas aeruginosa, and Eschericia coli (Kuo et al., 2017).

A study in Malaysia noted that in adults receiving chemotherapy with febrile neutropenia, $60 \%$ of the bacteria isolated was the gram-negative Enterobacteriaceae (Baskaran et al., 2007). In contrast, a study in Lebanon noted that gram-negative bacteria were responsible for $78.8 \%$ (22/33) of bloodstream infections compared to $33.3 \%$ (11/33) caused by gram-positive bacteria (Kanafani et al., 2007). The study reported that the dominant gram-negative bacteria were $P$. aeruginosa and E. coli. A possible explanation for these findings was the relatively low proportion of indwelling catheters (Raad et al., 2007). The different predominant bacteria reported in children compared to adults emphasize variations in the oral flora between them. It is important to note that the paediatric oral flora is more diverse than in adults (Villafuerte et al., 2018). Their response to treatment regimens may explain the differences in the quality of their oral microflora. 
We observed that there were more bacterial species reported in the post-cancer therapy group than in the precancer therapy group. The isolation count for opportunistic bacteria among those receiving cancer therapy was higher compared to pre-cancer treatment. Pathogenic bacteria such as $S$. aureus and $K$. pneumoniae were also isolated in this study in patients who had received cancer therapy. However, our results revealed no significant change in the isolation frequency of aerobic bacteria before and after receiving cancer therapies. The varying bacterial counts between the two groups may be due to the relative differences in the number of patients. A study on the oral microflora within dental plaques of patients with cancer reported that $57 \%$ had gram-positive cocci, whilst $43 \%$ of the bacterial flora were periodontal pathogenic species (Vozza et al., 2015). In contrast, Napeñas et al. (2007) reported no clear pattern regarding quantitative and qualitative oral flora changes among patients with cancer. Their study found that the most frequent gram-negative bacteria were from the Enterobacteriaceae family, Pseudomonas sp. and E. coli. Meanwhile, the most common gram-positive species isolated were Staphylococcus sp. and Streptococcus sp. (Joel et al., 2007).

$S$. salivarius and $S$. parasanguinis were the predominant bacterial isolates post-cancer therapy in our study. Similar findings were reported in a mutant and non-mutant streptococci survey in patients receiving radiotherapy (Tong et al., 2003). The study reported S. mitis, S. salivarius, and Lactobacilli as predominant isolates post-irradiation, with decreased $S$. sanguinis counts. A possible explanation is the increased acidic oral environment due to reduced salivary flow (Schubert \& Izutsu, 1987) thus altering normal oral microflora. Lactobacilli are known to grow well in acidic environment. Hence, a change in the environment may cause aciduric bacteria to survive and inhibit non-aciduric bacteria such as S. sanguinis (Schubert \& Izutsu, 1987). Therefore, the higher abundance of $S$. mitis and $S$. salivarius after radiotherapy would suggest a more acidified oral environment, increasing the risks of developing caries (Schubert \& Izutsu, 1987).

We acknowledged several limitations of this study. Firstly, the exclusion of anaerobic bacteria may preclude a better understanding of the oral microflora present in immunocompromised patients. Secondly, at the time of sampling, oral bacteria may have undergone selection after disease manifestation, with some bacteria inhibited and others thriving, resulting in divergent conclusions in various studies (Wang et al., 2014). While the traditional culture method is less costly, it is recommended that all cultivable bacteria be included in the analysis to fully understand the patterns of oral microflora and how they affect one another. Furthermore, there were lack of certain clinical information, such as the types of cytotoxic drugs used, periodontal examination, and other predisposing factors. Such data would be essential to determine how the micro-organisms can affect the clinical condition of children with cancer.

\section{CONCLUSION}

This study demonstrated the species of pathogenic bacteria present in the oral cavities of paediatric patients with cancer. These bacteria can affect the diversity of oral microflora and may result in systemic infectious diseases. The presence of non-pathogenic bacteria may be beneficial in maintaining species balance in the oral cavity. The findings from this study can facilitate the better understanding of oral diseases in children with cancer before and after treatment.

\section{ACKNOWLEDGEMENTS}

The authors wish to express their gratitude to all the patients and their families who voluntarily participated in this study. Special thanks go to all the health care workers for their technical assistance during the sample collection. This research work was funded by the Universiti Malaya Impact Oriented Interdisciplinary Research Grant (IIRG) (IIRG026C2019). The funders had no role in the study design, data collection and analysis, decision to publish, or manuscript preparation.

\section{Conflict of Interest}

All authors have no conflict of interest concerning the work reported in this paper.

\section{REFERENCES}

Abranches, J., Zheng, L., Kajfasz, J.K., Palmer, S.R., Chakraborty, B., Wen, Z.T., Richards, V.P., Brady, L.J. \& Lemos, J.A. (2018). Biology of oral streptococci. Microbiology Spectrum 6. https://doi.org/10.1128/microbiolspec.GPP3-0042-2018

Baskaran, N.D., Gan, G.G., Adeeba, K. \& Sam, I.C. (2007). Bacteremia in patients with febril neutropenia after chemotherapy at a university medical centre in Malaysia. International Journal of Infectious Diseases 11: 513-517. https://doi.org/10.1016/j.ijid.2007.02.002

Bertolini, M. \& Dongari-Bagtzoglou, A. (2019). The relationship of Candida albicans with the oral bacterial microbiome in health and disease. Advances in Experimental Medicine and Biology 1197: 69-78. https://doi.org/10.1007/978-3-03028524-1_6

Bowen, W.H., Burne, R.A., Wu, H. \& Koo, H. (2018). Oral biofilms: pathogens, matrix, and polymicrobial interactions in microenvironments. Trends in Microbiology 26: 229-242. https://doi.org/10.1016/j.tim.2017.09.008

Bunetel, L., Tamanai-Shacoori, Z., Martin, B., Autier, B., Guiller, A. \& Bonnaure-Mallet, M. (2019). Interactions between oral commensal Candida and oral bacterial communities in immunocompromised and healthy children. Journal de Mycologie Medicale 29: 223-232. https://doi.org/10.1016/ j.mycmed.2019.06.004

Cahill, T.J., Harrison, J.L., Jewell, P., Onakpoya, I., Chambers, J.B., Dayer, M., Lockhart, P., Roberts, N., Shanson, D. \& Thornhill, M. (2017). Antibiotic prophylaxis for infective endocarditis: a systematic review and meta-analysis. Heart 103: 937-944. https://doi.org/10.1136/heartjnl-2015309102

Castellazi, L., Mantero, M. \& Esposito, S. (2016). Update on the management of pediatric acute osteomyelitis and septic arthritis. International Journal of Molecular Sciences 17: 855. https://doi.org/10.3390/ijms17060855

Chimenos-Küstner, E., Giovannoni, M.L. \& Schemel-Suárez, M. (2017). Dysbiosis as a determinant factor of systemic and oral pathology: importance of microbiome. Medicina Clinica 149: 305-309. https://doi.org/10.1016/j.medcli.2017. 05.036

Curtis, M.A., Diaz, P.I. \& Van Dyke, T.E. (2020). The role of the microbiota in periodontal disease. Periodontology 83: 1425. https://doi.org/10.1111/prd.12296

Daugëlaitë, G., Upkuraitytë, K., Jagelavièienë, E. \& Filipauskas, A. (2019). Prevention and treatment of chemotherapy and radiotherapy induced oral mucositis. Medicina (Kaunas, Lithuania) 55: 25. https://doi.org/10.3390/medicina 55020025 
Dodwell, E.R. (2013). Osteomyelitis and septic arthritis in children: current concepts. Current Opinion in Pediatrics 25: 58-63. https://doi.org/10.1097/MOP.0b013e32835c2b42

Fernández, E., Reyes, C., Benavides, C., Irarrázaval, T. \& Padilla, P. (2018). Antimicrobial prophylaxis for transient bacteremia during dental procedures. Revista Medica de Chile 146: 899-906. https://doi.org/10.4067/s0034-988720 18000700899

Giunta Crescente, C., Soto de Facchin, M. \& Acevedo Rodríguez, A.M. (2018). Medical-dental considerations in the care of children with facial cellulitis of odontogenic origin. A disease of interest for pediatricians and pediatric dentists. Archivos Argentinos de Pediatria 116: e548-e553. https://doi.org/10.5546/aap.2018.eng.e548

Graves, D.T., Corrêa, J.D. \& Silva, T.A. (2019). The Oral Microbiota Is Modified by Systemic Diseases. Journal of Dental Research 98: 148-156. https://doi.org/10.1177/ 0022034518805739

Hong, B.Y., Sobue, T., Choquette, L., Dupuy, A.K., Thompson, A., Burleson, J.A., Salner, A.L., Schauer, P.K., Joshi, P. \& Fox, E. (2019). Chemotherapy-induced oral mucositis is associated with detrimental bacterial dysbiosis. Microbiome 7: 66 . https://doi.org/10.1186/s40168-019-0679-5

Idris, A., Hasnain, S.Z., Huat, L.Z. \& Koh, D. (2017). Human diseases, immunity and the oral microbiota-Insights gained from metagenomic studies. Oral Science International 14: 27-32. https://doi.org/10.1016/S13488643(16)30024-6

Kanafani, Z.A., Dakdouki, G.K., El-Chammas, K.I., Eid, S., Araj, G.F. \& Kanj, S.S. (2007). Bloodstream infections in febrile neutropenic patients at a tertiary care center in Lebanon: a view of the past decade. International Journal of Infectious Diseases 11: 450-453. https://doi.org/10.1016/j.ijid.2006. 12.008

Kitamoto, S., Nagao-Kitamoto, H., Hein, R., Schmidt, T.M. \& Kamada, N. (2020). The bacterial connection between the oral cavity and the gut diseases. Journal of Dental Research 99: 1021-1029. https://doi.org/10.1177/0022034520924633

Kong, E.F., Kucharíková, S., Van Dijck, P., Peters, B.M., Shirtliff, M.E. \& Jabra-Rizk, M.A. (2015). Clinical implications of oral candidiasis: host tissue damage and disseminated bacterial disease. Infection and Immunity 83: 604-613. https://doi.org/10.1128/IAI.02843-14

Kuo, F.C., Wang, S.M., Shen, C.F., Ma, Y.J., Ho, T.S., Chen, J.S., Cheng, C.N. \& Liu, C.C. (2017). Bloodstream infections in pediatric patients with acute leukemia: Emphasis on gram-negative bacteria infections. Journal of Microbiology, Immunology, and Infection 50: 507-513. https://doi.org/ 10.1016/j.jmii.2015.08.013

Lecomte, M., Begot, E., Barraud, O., Matt, M. \& François, B. (2017). Routine tooth brushing in the intensive care unit: A potential risk factor for oral flora bacteremia in immunocompromised patients. Medicina Intensiva 41: 5355. https://doi.org/10.1016/j.medin.2016.02.006

Liu, X.R., Xu, Q., Xiao, J., Deng, Y.M., Tang, Z.H., Tang, Y.L. \& Liu, L.S. (2020). Role of oral microbiota in atherosclerosis. International Journal of Clinical Chemistry 506: 191-195. https://doi.org/10.1016/j.cca.2020.03.033

Maraki, S. \& Papadakis, I.S. (2015). Rothia mucilaginosa pneumonia: a literature review. Infectious Diseases 47: 125129. https://doi.org/10.3109/00365548.2014.980843

Mira, A., Simon-Soro, A. \& Curtis, M.A. (2017). Role of microbial communities in the pathogenesis of periodontal diseases and caries. Journal of Clinical Periodontology 44: S23-S38. https://doi.org/10.1111/jcpe.12671
Miranda-Silva, W., Knebel, F.H., Tozetto-Mendozo, T.R., Palmieri, M., da Fonseca, F.P., Camargo, A.A., Braz-Silva, P.H. \& Fregnani, E.R. (2020). Herpesviruses in the oral cavity of patients subjected to allogeneic hematopoietic stem cell transplantation and its relationship with oral mucositis. Clinical Oral Investigations 24: 3597-3608. https://doi.org/10.1007/s00784-020-03234-3

Napeñas, J.J., Brennan, M.T., Bahrani-Mougeot, F.K., Fox, P.C. \& Lockhart, P.B. (2007). Relationship between mucositis and changes in oral microflora during cancer chemotherapy. Oral Surgery, Oral Medicine, Oral Pathology, Oral Radiology, and Endodontics 103: 48-59. https://doi.org/10.1016/ j.tripleo.2005.12.016

Nivoix, Y., Ledoux, M.P. \& Herbrecht, R. (2020). Antifungal Therapy: New and Evolving Therapies. Seminars in Respiratory and Critical Care Medicine 41: 158-174. https://doi.org/10.1055/s-0039-3400291

Patrakka, O., Pienimäki, J.P., Tuomisto, S., Ollikainen, J., Lehtimäki, T., Karhunen, P.J. \& Martiskainen, M. (2019). Oral bacterial signatures in cerebral thrombi of patients with acute ischemic stroke treated with thrombectomy. Journal of the American Heart Association 8: e012330. https://doi.org/10.1161/JAHA.119.012330

Philip, K., Teoh, W., Muniandy, S. \& Yaakob, H. (2009). Pathogenic bacteria predominate in the oral cavity of Malaysian subjects. Journal of Biological Sciences 9: 438444. https://doi.org/10.3923/jbs.2009.438.444

Priyamvara, A., Dey, A.K., Bandyopadhyay, D., Katikineni, V., Zaghlol, R., Basyal, B., Barssoum, K., Amarin, R., Bhatt, D.L. \& Lavie, C.J. (2020). Periodontal inflammation and the risk of cardiovascular disease. Current Atherosclerosis Reports 22: 28. https://doi.org/10.1007/s11883-020-00848-6

Raad, I., Hachem, R., Hanna, H., Bahna, P., Chatzinikolaou, I., Fang, X., Jiang, Y., Chemaly, R.F. \& Rolston, K. (2007). Sources and outcome of bloodstream infections in cancer patients: the role of central venous catheters. European Journal of Clinical Microbiology \& Infectious Diseases 26: 549556. https://doi.org/10.1007/s10096-007-0320-6

Sampaio-Maia, B., Caldas, I.M., Pereira, M.L., Pérez-Mongiovi, D. \& Araujo, R. (2016). The oral microbiome in health and its implication in oral and systemic diseases. Advances in Applied Microbiology 97: 171-210. https://doi.org/10.1016/ bs.aambs.2016.08.002

Schubert, M.M. \& Izutsu, K.T. (1987). latrogenic causes of salivary gland dysfunction. Journal of Dental Research 66: 680-688. https://doi.org/10.1177/00220345870660\$213

Sixou, J.L., De Medeiros-Batista, O., Gandemer, V. \& BonnaureMallet, M. (1998). The effect of chemotherapy on the supragingival plaque of pediatric cancer patients. Oral Oncology 34: 476-483. https://doi.org/10.1016/s13688375(98)00062-1

Tang, Y.J., Su, Y., Cao, Q. \& Gao, Y.J. (2020). Microbiologically documented bloodstream infection in children with malignancies: A single-center experience. Journal of Pediatric Hematology/Oncology 42: e558-e562. https:// doi.org/10.1097/MPH.0000000000001768

Tong, H.C., Gao, X.J. \& Dong, X.Z. (2003). Non-mutans streptococci in patients receiving radiotherapy in the head and neck area. Caries Research 37: 261-266. https://doi.org/ 10.1159/000070868

Verma, D., Garg, P.K. \& Dubey, A.K. (2018). Insights into the human oral microbiome. Archives of Microbiology 200: 525540. https://doi.org/10.1007/s00203-018-1505-3 
Villafuerte, K., Martinez, C., Dantas, F.T., Carrara, H., Dos Reis, F. \& Palioto, D.B. (2018). The impact of chemotherapeutic treatment on the oral microbiota of patients with cancer: a systematic review. Oral Surgery, Oral Medicine, Oral Pathology and Oral Radiology 125: 552-566. https://doi.org/ 10.1016/j.0000.2018.02.008

Vozza, I., Caldarazzo, V. \& Ottolenghi, L. (2015). Changes in microflora in dental plaque from cancer patients undergoing chemotherapy and the relationship of these changes with mucositis: A pilot study. Medicina Oral, Patologia Oral y Cirugia Bucal 20: e259-e266. https://doi.org/ 10.4317/medoral.19934

Wang, Y., Xue, J., Zhou, X., You, M., Du, Q., Yang, X., He, J., Zou, J., Cheng, L. \& Li, M. (2014). Oral microbiota distinguishes acute lymphoblastic leukemia pediatric hosts from healthy populations. PloS One 9: e102116. https://doi.org/ 10.1371/journal.pone.0102116
Ye, C., Xia, Z., Tang, J., Khemwong, T., Kapila, Y., Kuraji, R., Huang, P., Wu, Y. \& Kobayashi, H. (2020). Unculturable and culturable periodontal-related bacteria are associated with periodontal inflammation during pregnancy and with preterm low birth weight delivery. Scientific Reports 10: 15807. https://doi.org/10.1038/s41598-020-72807-9

Zhang, Y., Wang, X., Li, H., Ni, C., Du, Z. \& Yan, F. (2018). Human oral microbiota and its modulation for oral health. Biomedicine \& Pharmacotherapy 99: 883-893. https://doi.org/ 10.1016/j.biopha.2018.01.146 